\title{
METHOD OF NAHWU IN ARABIC LEARNING
}

\author{
M. Asy'ari
}

State Institute For Islamic Studies Palu

Lere, Kota Palu, Cebtral Sulawesi, 4221

E-mail: asyari1204@gmail.com

\begin{tabular}{c|c|c}
\hline Received: & Revised: & Approved: \\
02/08/2019 & $01 / 09 / 2019$ & $08 / 10 / 2019$ \\
\hline
\end{tabular}

DOI: http://dx.doi.org/10.32332/akademika.v24i2.1821

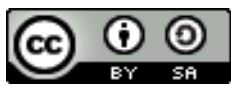

Method of Nahwu in Arabic Learning Licensed Under a Creative Commons Attribution-ShareAlike 4.0 International License

\begin{abstract}
Language is very important and the impression that Nahwu is a difficult science to learn, especially by Muslims. As one of the basic sciences in Arabic, Nahwu's science cannot be ignored because without Nahwu's knowledge, Arabic will become chaotic and the order of words and sentences will be disorganized. Therefore, in learning Arabic, it is important to know Nahwu's knowledge, even though this method of teaching science is quite widely practiced by nahwu teachers, but students continue to face difficulties in learning it. Therefore, it is necessary to use suitable teaching methods and appropriate steps and subject matter that must be prioritized to be taught to students, so as to facilitate them in learning Nahwu science. ${ }^{1}$ Related to this, there are a number of issues that need to be discussed, namely: What is the importance of learning nahwu, especially by students who want to communicate in Arabic ?; What method should be used so that students can learn nahwu easily? Here are some important questions that will be discussed in this article.
\end{abstract}

Keywords: Nahwu, Learning, amd Arabic

1 Rafi'i, "Ibn Mada's Thoughts and Efforts of Ulama XX Century in Nahwu Reformation, 144. 


\section{A. Introduction}

Nahwu according to language is الطريق و الجهة (road and direction) .According to Al-Ra'az (1992: 133), nahwu is القصدو الطريق. However, according to the classical cleric terms is limited to the discussion of the problem of الإعراب و البناء (i'râb and binâ ' ), ${ }^{2}$ namely the determination of the end line of a word according to its position in the sentence (الجملة) which they define as follows:

Nahwu are rules that can recognize Arabic ihwalkata, both in terms of i'rab and bina ' (Biek, et al, t.th .: In this day and age, after the development of research and studies on linguistic analysis, scholars tends to change and broaden the understanding of nahwu science, not just centering on the discussion of ' syab and bina' for a word, but it can also include a discussion of networking vocabulary, interrelationship between several words, the union of several words in a particular soundtrack and the relationship between words in the sentence. and the components that make up a disclosure or phase.

One thing that cannot be denied is the recent development of this new understanding of nahwu science while still maintaining the urgency of Arabic. The reason is that the $i^{\prime} r a b$ is an inseparable part in the formation of Arabic sentences, where without $i^{\prime} r a b$, an Arabic sentence will not be perfect, the characteristic of its Arabic will be lost if the $i^{\prime} r a b$ is imperfect. The tendency of a group of people to leave the problem i'rab because feeling enough to be convinced at the end of each word is an unacceptable tendency. However, in order not to be too difficult for students, nahwu science material that will be taught must be effective in its use in Arabic everyday and is directly related to the basic function of nahwu, namely the determination of the end of the line and how to form perfect sentences. As for the profound things about nahwu, his teaching was postponed. Some things in learning the science of nahwu whose teaching needs to be postponed, among others: ' i'râb takdîrî which is in the max $i s m^{3}$, ism mankûs and ism that are mudâf to yâa 'al-mutakalimûn; 'I'rab mahallî; · Tasghîr; fi'l that mabnî; letter zâidah; · Ta'ajjub who has a af'al-bih; asmâ 'af'âl; $n \hat{a}$ 'ib al-fâ'il which consists of al-zarf and al-jār wa al majrûr; ·Jazm al-mudari ' as jawâb shart; adawât al-shart that does not answer; al-istighâthah; ·AlNadbah.

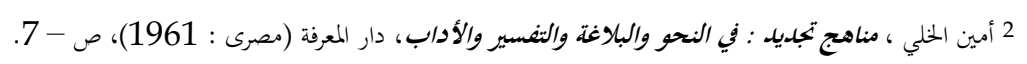

3 Ahmad Fuad Effendy, Arabic Language Teaching Methodology (Malang: Misykat, 2005), 3rd cet, 86 . 


\section{B. Some Learning Methods.}

Methods are indispensable in a study, which is to help solve and identify the problem to be examined, as well as used to show how this theory is used and analyzed in a study. Theory is a set of hypotheses used to explain language data, is outward and this theory applies to all studies of Epistemology, because according to different definitions the theory is a set of definitions and concepts. In presenting a systematic view, a phenomenon shows the relationship between one variable and another because it is intended to explain and predict phenomena. In this theoretical study, there are two main theories that I will use, namely the theory of systemology and the theory of Usul al-Nahwi.

Based on the theory of Epistemology, science basically develops through certain parts, including ${ }^{4}$ :

1. Rational Method (Manhajal-'aqli), intended that the method in a rational way and based on existing facts can add and develop existing scientific studies. ${ }^{5}$

2. Intuitive Method (Manhaj al-zauq), intended that the method of describing and researching in terms of existing scientific studies to add to the scientific treasures.

3. Dialogical Method (Manhaj al-jadl), intended that the method is dialogically or collide with arguments and add knowledge from each study of science.

4. Comparative Method (Manhaj al-muqa <ran), intended that the method by comparing a theory or concept that already exists in order to be able to add and complete each of the scientific studies.

5. Method of Criticism (Manhaj al-naqdi), intended that the method by way of criticizing or providing new things for a science branch so as to provide implementation and improvement for the science itself. Systemology focuses on the meaning of knowledge connected with the concepts, sources and criteria of knowledge, types of knowledge, and so on. In another sense, both science and theory are a very essential part of man because he is the fruit of thinking. The fruit of science or theory is not born suddenly, but through a process, like a fruit that grows from a tree, and this shows its natural nature. The importance of an epistemology departs from an assumption. ${ }^{6}$ that even a thought

$$
4 \text { سعيد الأفغاني، من تاريخ النحو، دار المعرفة (بيروت : 1972) ص - } 17 .
$$

${ }^{5}$ Jonathan A. smith, Fundamentals of Qualitative Psychology ; Practical Guidelines for Research Methods , ( Bandung: Nusa Media, 2006) , 103.

${ }^{6}$ A. Susanto, Philosophy of science : a study in Dimen the Ontological, epistemological and axiological, cet. 2, (Jakarta : Earth Literacy 2001), 102. 
which has reached a level of reflection cannot be satisfied by returning to common assumptions or common sense, 13 but it is very urgent to advance to a new level because the certainty sought by epistemology is made possible by such doubts.

Epistemology is basically reflective, any general assumption can be used as a reflective question. If epistemology succeeds in circulating this doubt, we might find reflective certainty that is more appropriate for knowledge. Epistemology is one of the most difficult parts of systematic philosophy, and therefore epistemology reaches issues that stretch as broad as the scope of physics itself, so that nothing can be removed from it.7

Language learning methods, including Arabic, have evolved over time along with the development of the underlying theories, the results of research and experimentation in language teaching, as well as the development of the demands of the community's needs in the language field. In this section, we will discuss learning methods, which include (1) understanding of learning methods, (2) benefits of learning methods, (3) types of language learning methods, and (4) factors that influence the selection of learning methods.

\section{Understanding Learning Methods}

A global method is a tactic, a trick or a way to do something to achieve a certain goal. The method according to language (etymology) comes from Greek, namely meta (along), hodos (road). Logi comes from the word Logos meaning "study of" or "theory of" So, method" is a knowledge of the ways or steps taken in a particular discipline to achieve certain goals. Method means the knowledge of how to convey something to others. The method is also called teaching or research.

According to the term (terminology), a method is a teaching that gives a description, explanation, and determination of values. The usual method is used in scientific inquiry. Hugo F. Reading said that the method is the logic of scientific research, systems of procedures and research techniques.

When a method is combined with the word logos the meaning changes. Logos means "study of" or "theory of". Therefore, the methodology is no longer just a collection of ways that have been received (well received) but in the form of a study of methods. In the methodology the study of the workings of science is discussed. In short, if there are no differences in the method, reflection and study of the workings of science, in contrast to the wide

${ }^{7}$ Louis O. Katsoff , Ibid., 135.

8 Juwairiyah Dahlan, Arabic Language Teaching and Learning Methods, AlIkhhlas (Surabaya; 1992), Cet I, p.103. 
open methodology for studying, debating, and reflecting the workings of a science. Therefore, methodology becomes a part of systematic philosophy, whereas method does not. The method is the science of ways and steps that are appropriate (to analyze something) explanation and apply methods.

The method in Arabic, called ath-tharigah, is a comprehensive plan that deals with the regular presentation of Arabic material, there is no one contradictory part to the others which are all based on the chosen approach. Procedural in nature. The method is a systematic way of working to facilitate the implementation of an activity in order to achieve the specified goals The method is more procedural and systemic because the aim is to facilitate the work done according to Anthony, the method is an overall plan for the presentation of materials in a neat and orderly manner, for which there are no parts that contradicts, and all of it is based on a chosen approach. If the approach is axiomatic, the method is procedural. Huda gave two conclusions about learning, namely: (1) learning as a change in behavior. One example of this change is when a learner who initially is not so attentive in class turns out to be very attentive, and (2) learning as a change in capacity. One example of this change is when a learner who is initially afraid of a particular student turns out to be someone who is very confident in completing the student.

Then Chatib concluded that the learning method can be interpreted as a method used to implement the arrangement of plans in the form of real and practical activities so that learning objectives are achieved. Whereas according to the language learning method is a comprehensive plan for the systematic presentation of language based on the prescribed approach.

Each language learning method basically wants the same result so that students can read, speak, understand, translate, and recognize the applications of grammar (foreign) that are taught. The method is a way of carrying out the work, while the approach is philosophical, or axiomatic. Thus, the method is procedural. That is, describe the procedure of how to achieve teaching objectives. So it can be concluded that the learning method is a way for full planning in presenting student material on a regular basis in different ways to achieve different learning outcomes under different conditions or comprehensive ways (from beginning to end) in the same order systematically based on certain approaches to achieve learning goals such as changing behavior and increasing student knowledge. 


\section{Benefits of Learning Methods.}

Arsyad (2007b: 15) states that there are two very important elements in learning, namely the teaching method and the media. Both have an interrelated relationship because the method of teaching influences the selection of instructional media. As the learning function is trying to change the input in the form of students who have not been educated, become students who are educated, students who do not have knowledge about something, become students who have knowledge, then effective learning is characterized by the learning process in students. According to Djamarah and Zain (2006: 82), the benefits of learning methods include:

\section{a. Extrinsic Motivation Tool}

Extrinsic motivation is active and functioning motives due to external stimuli. The learning method serves as an external stimulant that can arouse student learning.

\section{b. Learning strategies}

The students' absorption of the material provided also varies. Some are fast, some are moderate, and some are slow. Intelligence factors affect students' absorption of student material provided by the teacher. Differences in students' absorption abilities require appropriate learning strategies, and methods are one solution. For a group of students it may be easy to absorb student material if the teacher uses the question and answer method, but for another group of students. Herein lies the function and benefits of learning methods.

\section{c. Tools for Achieving Goals}

The function of the learning method is one tool to achieve the goal. ${ }^{9} \mathrm{By}$ using methods accurately the teacher will be able to achieve the learning objectives. When goals are formulated so that students have certain skills, the methods used must be adapted to the goals.

According to Syah (2007: 134), learning methods can create a good, effective and efficient teaching and learning interaction. Because the selection of teaching methods that are good and effective and right on target will increasingly create better educational interactions as well.

From the above explanation, it can immediately be seen that in essence the method aims to deliver a learning towards certain ideal goals precisely and quickly as desired. Therefore there is a general principle in the functioning of the method, namely the principle that learning can be carried out in a pleasant atmosphere, encouraging full of encouragement

\footnotetext{
9 Basyuni, et.al, Analysis, Journal of Islamic Studies, (Lampung; 2006), 125.
} 
and motivation so that the learning material becomes easier to be accepted by students.

\section{Types of Language Learning Methods}

The development of post-Direct Language learning methods namely since the thirties developed very rapidly along with the development of studies in the field of linguistics and psychology. Some experts in the field of language divide the method into many types and describe it according to the times and needs in the world of language learning.

From the history of development from the past until now known and known to a variety of methods of language learning. Most of the methods that developed over the past few centuries are still used today in one or several forms in various parts of the world. The types or types most commonly used according to William Francis Hackey, Danny D. Steinberg, and Etern are summarized by Tarigan as follows:

\section{a. Grammar Translation Method}

This method emphasizes the target grammar words and the practice of the main practice is the +translation from and into the target language or target language. This lack of orientation towards the purpose of the skill is the most obvious and most prominent weakness or weakness in this method.

\section{b. Direct Method}

This Direct Method in its implementation must be in the target language so that aspects of speaking and listening skills get more attention. The Direct Method is based on grammar, so this clearly constrains its ability to present messages that are really interesting and tend towards overuse of the monitor.

\section{c. Audiolingual Method}

The Audiolingual Method prioritizes dialogue in language presentation and emphasizes exercises and separates language skills and audiolingual excellence over graphic skills. In other words, there has not been an explicit attempt to limit the learning of rules that are learned, easily carried, and that have not been obtained, nor has there been any effort to encourage the use of rules only in certain situations.

\section{d. Cognitive Approach}

This theory or method is interpreted by some experts as "the latest, modified grammar translation theory". The main goal is to develop the ability of native speakers in students.

\section{e. Dual Approach}

This dual approach is a modern adaptation of the Direct Method which is closely related to another variant known as the Verbal Active Method. The 
dual approach has advantages and disadvantages..$^{10}$ If it is managed properly, it will give a double benefit, if it is not managed properly, it will also cause double losses.

\section{f. Total Physical Response}

This method consists of structuring or obeying commands and commands given by the instructor / teacher which involves a clear physical response by developing speaking activities in language understanding and using body movements when responding is a means of gaining understanding.

\section{g. Natural Approach}

The natural approach aims to increase direct communicative competence, improve formal grammar, prioritize semantic / vocabulary goals. This approach remains a class method, and for some students it hinders or is an obstacle to communicating topics that are interesting and relevant.

\section{h. Community Language Learning}

This method, also called Community Language Learning, is an indirect approach designed to facilitate the learner in being independent and trusting in the target language. Many demands must be met by teachers or teachers in teaching languages that apply this method, thus making teachers reluctant to use this method.

\section{i. Communicative Language Teaching}

The purpose of learning by using a method or method. ${ }^{11}$ This is developing students' competence in communicating with the target language in the actual communicative context or in real life situations. Learning does not emphasize mastery of grammatics or making grammatical sentences, but rather the ability to produce speech that is appropriate to the context.

\section{j. Situational Language Teaching}

Situational Language Teaching starts with oral language then reads and writes, starts when the lexical and grammatical foundation is sufficient. The principles of this method have a strong emphasis on oral practice, grammar, and sentence patterns that can adjust to the intuitions of teachers who are class-oriented.

${ }^{10}$ Ismail Fahmi, Ulumuna, Journal of Islamic Studies, (Mataram: 2012), 27.

11 Abu Bakar Muhammad, Special Method of Teaching Arabic, National Business, (Malang; 1981), 54. 


\section{k. Audiovisual Method}

Audiovisual method is a method that utilizes psychodynamic interpretation and is very reflexive. This method turned out to be better at producing phonological abilities than communicative abilities. This method turned out to be far more suitable and satisfying for younger students than for older students, the same age as students.

\section{Reading Method}

Key features include (1) separation of active and passive phases, (2) grammatical analysis approach, (3) emphasis on intensive and extensive reading experience, (4) postponement of speaking and writing training, (5) continuous attention to words verbal words, (6) attention to individual learners.

\section{m. Teaching Foreign Languages in Primary Schools}

In other words, this method is used to support foreign language teaching programs for elementary school students to get accustomed to using the target language, so that in the next level the difficulties of teaching a foreign language can be minimized and able to increase student mastery of the target language. ${ }^{12}$

\section{n. Suggestopedia}

Suggestopedia is a relaxation and concentration technique that will help learners open up their unconscious sources and obtain and master a greater quantity of vocabulary and also structures that are more stable than they might have thought, this method is also known as Learning and Teaching Suggestive Aselerative or Lozanov Method.

\section{o. Structural-Oral-Situational Method}

Learning methods that believe that the form of language can be best studied if the learners focus more on meaning than on form. Meanwhile, according to Iskandarwassid and Sunendar (2011: 56-66), the language learning method is slightly different from what has been described above, there are 16 types including: Grammar Translation Methods, Reading Methods, Audio-Lingual Methods, Receptive and Productive Methods, Direct Methods, Communicative Method, Integrative Method, Thematic Method, Quantum Method, Constructivistic Method, Participatory Method, Contextual Method, Community Language Learning Method, Total Physical Response Method, Silent Method Method, and Suggestopedia Method.

In addition to the several language learning methods proposed according to some of the linguists and language experts above, there are

12 Ardianto, Attitude of language Social studies of linguistics , PT .UNM (Malang: 2012), 43. 
also language learning methods that are specialized for learning Arabic and here the researcher refers to Ahmad Fuad Effendy's opinion. Effendy (2009: 40-95) classifies Arabic learning methods into six types, namely; The Grammatic Translation Method ( Tariqah Al-Qowaid wa At-Tarjamah), the Direct Method (Ath-Tariqah Al-Mubasyarah), the Reading Method ( Tariqah Al-Qira'ah), the Audiolingual Method (Ath-Tariqah As-Sam'iyyah AsSyafahiyyah)), Communicative Method (Ath-Thariqah Al-Ittishaliyah), and Eclectic Method (Ath-Thariqah Al-Intiqaiyyah ).

\section{p. The Grammatic Translation Method (Tariqah Al-Qowaid wa At-} Tarjamah )

In our country Indonesia, this method is still used today in Islamic boarding schools which are commonly referred to as salafi boarding schools. Students with this method are encouraged to memorize classic texts in foreign languages and their translations in the language of the students, especially those with high literary value, even though they often contain complex sentence structures and unused vocabularies or expressions.

\section{q. Direct Method (Ath-Tariqah Al-Mubasyarah)}

This method was developed on the basis of the assumption that the process of learning a second language or a foreign language is the same as learning mother tongue, namely by using language directly and intensively in communication, and by listening and speaking, while composing and reading. then. Therefore students must be accustomed to thinking in the target language and the use of student language is avoided altogether.

\section{r. Reading Method ( Tariqah Al-Qira'ah)}

This method is developed based on the assumption that language teaching cannot be multi-purpose, and that the ability to read Arabic words ${ }^{13}$ is the most realistic goal in terms of the needs of foreign language learners. As such, the assumptions are pragmatic, not theoretical philosophical.

\section{s. Audiolingual Method (Ath-Tariqah As-Sam'iyyah Ash- \\ Syafahiyyah )}

One of the sums of this method is that language is habit. A behavior becomes a habit if repeated many times. Therefore, language teaching must be done with repetition or repetition techniques. Mastery of sentence patterns are applied to the communicative method is done with the exercises pattern (pattern-practice). The drill follows the sequence: stimulus $>$ response $>$ reinforcement .

${ }^{13}$ Misbahuddin Jamal, Understanding the language of the Koran, STAIN Manado Press, (Malang: 2013, Cet I, 47. 


\section{t. Communicative Method ( Ath-Tariqah Al-Ittishaliyah)}

The communicative method is based on the assumption that every human being has an innate ability called a "language acquisition device". Therefore language skills are creative and are more determined by internal factors. Therefore the relevance and effectiveness of habituation activities with stimulus $>$ response $>$ reinforcement training models .

\section{u. Eclectic Method (Ath-Tariqah Al-Intiqaiyyah)}

Eclectic Method is a selection or combination method. This method can be an ideal method if it is supported by the mastery of the teacher's adequate story of a variety of methods, so that it can take precisely the power aspects of each method and adjust it to the needs of the teaching program it is handling, then apply it proportionally.

Thus some opinions of experts about the variety or types of methods of learning languages and Arabic. Departing from a variety of literature that researchers catch the still shortcomings in these methods which are not prostudents. Then, without prejudice to the methods already existed before, researchers will develop methods of learning new skills-based Arabiclanguage interpretation theory of multiple intelligences (multiple intelligences ) which is expected to side with the students and to improve student understanding in reading skills later.

\section{Factors that Influence Learning Method Selection}

Djamarah and Zain put forward five kinds of factors that influence the use of learning methods (1) objectives that understand Language types and functions, (2) students with varying degrees of maturity, (3) various situations (4) various facilities varying quality and quantity, (5) personal teacher and different professional abilities.

The most important criterion in the selection of learning methods is that the methods must be adapted to the learning objectives or competencies to be achieved. In addition, there are other complementary criteria, such as: usability, student situation, and technical quality.

Meanwhile, according to Iskandarwassid and Sunendar there are six factors affecting the selection of learning methods, namely as follows:

First, the characteristics of students. These characteristics include mental maturity and intellectual skills, physical condition and psychomotor skills, age, and gender. Second, basic competencies are expected. Namely a minimal or adequate statement of knowledge, skills, attitudes, and values reflected in the habits of thinking and acting after students complete one aspect or sub-aspect of a particular student's eye. Third, teaching materials. Submission of teaching materials in the form 
of facts, of course learning methods will be different from the delivery of teaching materials in the form of skills. Similarly, the principles and concepts, will have different learning methods. Fourth, the time available. To achieve a number of basic competencies that must be achieved, learning requires appropriate methods so that everything that becomes the goal of learning can be achieved appropriately within a specified time period. Fifth, learning facilities and infrastructure. The availability of learning facilities and infrastructure certainly greatly influences the choice of methods to be used. Sixth, the ability and skills of teachers to choose and use language learning methods and many practices. ${ }^{14}$ This ability is related to the accuracy of the selection of approaches, methods, and learning techniques that are harmonious and harmonious.

Thus it can be concluded, that to choose an appropriate learning method, a teacher or instructor is influenced by several factors which, namely the characteristics of the method, the characteristics of students, situations and conditions, facilities / facilities available, the expected objectives or basic competencies, materials the available teaching, the time available, and the abilities and skills possessed by the teacher in choosing the appropriate method.

\section{Purpose of the Nahwu Learning Method.}

We may agree that learning this Nahwu method is not a target for learning objectives, but that nahwu science, is one of the tools to help us speak and write correctly and straighten and keep our tongues from mistakes, also helps in exposing the teachings carefully, proficient and fluent. Some of the goals of teaching nahwu are: to guard and prevent oral and written from language errors, in addition to creating fluent language habits. That is why, the Arab and Islamic scholars of the past tried to formulate nahwu science in addition to safeguarding the language of the Qur'an and the Hadith of the Prophet Muhammad and to familiarize Arabic students with always observing. National Culture ${ }^{15}$ then think logically and regularly and other uses that can help them to critically study Arabic language; help students to understand Arabic expressions so that it accelerates the understanding of the purpose of talking in Arabic to sharpen the brain, enlighten feelings and develop students' language

${ }^{14}$ Tayyar Yusuf et.al , Op.cit, 109

15 Juwairiyah Dahlan, Arabic Language Teaching and Learning Methods, AlIkhlas (Surabaya; 1992), 29. 
treasures; gives students the ability to use Arabic rules in various linguistic settings.

Therefore, the most desirable outcome of teaching ilmunahwu is the ability of students in applying the rules in Arabic expression styles used by Arabic students in their lives, as well as being useful for understanding the classical language inherited by ancient olepara scholars. Sehri bin Punawan, the Nahwu Teaching Method or $q$ awaid can provide careful control to students when composing an essay.

\section{Nahwu Method in Learning Arabic.}

1. Understanding Method e Nahwu.

A global method is a tactic, a trick or a way to do something to achieve a certain goal. The method according to language (etymology) comes from Greek, namely meta (along), hodos (road). Logi comes from the word Logos means "study of" or "theory about" So, the method is a science of the ways or steps taken in a particular discipline to achieve certain goals. Method means the knowledge of how to convey something to others. The method is also called teaching or research.

According to the term (terminology), a method is a teaching that gives a description, explanation, and determination of values. The usual method is used in scientific inquiry. Hugo F. Reading said that the method is the logic of scientific research, systems of procedures and research techniques.

When a method is combined with the word logos the meaning changes. Logos means "study of" or "theory of". Therefore, the methodology is no longer just a collection of ways that have been received (well received) but in the form of a study of methods. In the methodology the study of the workings of science is discussed. In short, if there are no differences in the method, reflection and study of the workings of science, in contrast to the wide open methodology for studying, debating, and reflecting the workings of a science. Therefore, methodology becomes a part of systematic philosophy, while the method does not.

Methodology is the science of ways and steps that are appropriate (to analyze something) and explain explanations and ways. In the old view of Nahwu's teaching methods, students were required to memorize the rules, even though they did not understand them. As a result, they did not succeed in implementing it in the real world, the rules they had memorized. This happens a lot in Islamic boarding schools in Indonesia, also in several Arab countries. From this arises thought to look for solutions to how to overcome this problem, of course among the ways to overcome them is to find the best and easiest method to deliver your messages to students. If you pay attention to Arabic teaching methods in Arab 
countries, also in some Islamic boarding schools in Indonesia, both It was once practiced in the past, then stopped or which is still used until now, also which has been replaced by other methods, it can be discovered that these methods can be grouped into two main methods, namely the methods of القياسية (analogical) and the methods of الاسنتر ائية (inductive), each of which will be grouped into two main methods, i.e. described below.

\section{a. Method القياسية (Analogy)}

This method is sometimes called the rule method and for example, is the oldest method applied in the teaching of Nahwu science. Although this method is the oldest, but up to now it is still widely used in various educational foundations both in Arabic and in Indonesia, especially pesantren. In this method, teaching emphasizes the presentation, the imposition of memorizing the rules on students, then giving examples to clarify the purpose of the rules. ; this means that the learning process takes place from the general nature to the specific nature. The idea of قياس was born based on the desire that students understand the purpose of general rules that cling to their minds, which is the reason, teachers or students are required to analogize the example of Journal Hunafa, new who are still blurred to other examples that are clear, and then match with the general rules earlier.

Many people challenge this method with the excuse that: regardless of developing the ability to apply it, it might be suitable for people who specifically study Arabic bilingual but not suitable for children whose schools are scientific for them is to be practiced not to memorize. With this method often times students are ignorant of learning or the teacher, because of the attitude of passive students, even if there are students who participate, the number of students is not large. Contrary to the principles of teaching that want to start from the easy, then gradually to the difficult, from the concrete to the abstract; it is certain that prioritizing the faith from the example will create frustration and hardship. Students can forget the rules that they have memorized because they simply memorize them, without understanding them. This method is widely opposed by many teachers, because it will disrupt the attention of students, also because it separates between rules and language, so that it seems that they memorize it, without understanding it. nahwu as a book of nahwu zamandahulu followed the course of this method, as in the book of al-Ajrûmiyyah, alNahw al-wāf by Abbâs H $\square$ asan, Jami 'al-Durûsal-'Arabiyyah by Al-Gulayaini, the book Qawâ'id al-Lughah al-Lughah al -Arabiyyah compiled by Hafni Beik Fate, et al. as well as many other books in tune with the books above.

b. Method ( Induction ). استقرائية. 
This method is sometimes given the name استتباطية, استتناجية or Herbart Karen method following the five steps that must be taken in teaching as determined by Johan Priedrich Herbart. At first this method entered the Arab world after an invitation from a delegation of teaching missions from Europe in the early XX century, where the teaching style in this method was the opposite of the قياسية method, because this method was based on the presentation of examples first and then the examples were discussed with students, compared, and formulated rules and then given training to students. This method starts from the specific one to achieve general rules, while قياسية from the general to the specific. The proponents of this method are of the view that this kind of method is a natural method because students through examples of literary words, Azab and misery ${ }^{16}$, this can be to attain knowledge, expose ignorance, enlighten the obscure by recognizing its elements, gathering vocabulary and combining things with their like; this is done in stages until it comes to a general formula or comprehensive rules. Supporters of this method argue that with this method students will be active, whereas the teacher is only as a guide and guide. So, it is the students who are actively seeking to obtain the desired formula after discussing and linking and comparing the examples; it is students who solve problems. Strictly speaking, students are preoccupied with discussion activities so there is no chance to be quiet or ignore the lesson.

However, according to the author, however, this method cannot be separated from the weaknesses of which are that this method is slow and ineffective in conveying information, the examples presented by the teacher are also limited and there is a desire to immediately arrive at the formulation of the rules. But even so, many Arab countries are applying this method in schools. In addition, there are many books currently compiled according to this method, such as: Kitab al-Nahwu al-Arabiyyah li al-Nâshi'în. This method of استقرائية can be divided into two parts, namely: (1) the example method, those are examples that have nothing to do with the others, then the rules; and (2) the full text method, which is a text that has complete meaning, examples, and rules.

\section{c. Example Method .}

Also called an example method artificial, independent, scattered or cut; this naming arises because the examples are scattered and fragmented; cut into pieces taken from various sources that are not oneway. Advantages of the sample method The proponents of this method argue

16 Praise Santosa, Knowledge and appreciation of Literature, Nusa Indah (Jakarta; 1996) cet I, 95. 
that this method provides an opportunity for a teacher to choose examples freely, also can help the teacher and students to accelerate the course of learning. They are of the view that this method is easy to use so it is very helpful in learning Nahwu, where there are students who truly understand the rules, the tongue will be more eloquent and the person who explores the rules of the examples mentioned earlier in addition will be able to help the teacher to finish all the core topics that are in his syllabary, he can also overcome the problems posed by the curriculum.

\section{d. Whole Text Method}

This method is often called the continuous context method, perfect text or resaffle method, because this method is the result of changes in the previous teaching method. This method concentrates on the presentation of a whole text or essay taken from reading books, literary texts, historical material, daily newspapers or weekly magazines or the like, preferably those texts which contain events that are still warm in the minds of students.

The obligation of teachers in applying this method adalahmenjalankan the text, and then discuss how to address topikbacaan (قراء), then take the example of the text that dapatdijadikan basis as the subject matter then went langkahlangkahyang should be taken according to the methods Excess Text Method Whole Proponents of this method holds that pengajarannahwu through the approach of language gaps will bring stability, students will also feel the contact between language and life, so they love nahwu instead. Besides the integration between language exposure (( تعبير who is fluent with nahwu science will stabilize children in grammar and style-style, including how to read the Arabic language. This method will prevent the teacher from the burden of telling students to memorize what they do not understand. Weaknesses of Whole Text Method and style including its iabab. The full text method has weaknesses, including: - Some teachers find it difficult to find or create texts that can accommodate all the problems of sub subject matter, because sometimes teachers face difficulties to deal with it, as a result, sometimes many languages are damaged. ${ }^{17}$ To touch all sides of the desired principle, teachers are usually forced to make very long texts up to one page or more. As a result, the teacher will face two things dilemma. The teacher discusses the long text perfectly, from the introduction, reading discussing with students, explaining its meaning to selecting the desired examples.

In this case, there is not enough time to explain the lesson. The time devoted to doing the exercises is reduced, not to mention the students do

17 Tayyar Yusuf, Opcit, 78. 
not have enough time to arrange the correct kawaid.o Or the teacher ignores the text and immediately selects examples, explain and discuss them briefly without satisfying students. In this case, the teacher has deviated from the ideal teaching method, which is a method that can associate between nahwu adequate discussion and satisfying training and education that requires that kawaid should be taught under the auspices of literary language texts.

After the presentation of methods that have been used in teaching nahwu, and given the lack of research conducted to find the right method in teaching nahwu, it is not easy for us to overestimate one particular method by underestimating the other methods. Each method has supporters and opponents ${ }^{18}$, has weaknesses and strengths. From here it may be very necessary to have intensive field research to choose or create a method that is more suitable to be applied. Certainly it is not allowed to decide on the effectiveness of any of these methods except through field experiments conducted by people who master the Arabic language teaching methods. It should be noted that a teacher who can be assessed succeed here is a teacher who is able to profit from the advantages of the two methods, القياسية and الاستقرائية which is a teacher who knows when and where each method must be used and then applied according to his knowledge, given that qawaid, rules and any principles will be of any use if the a teacher doesn't know.

According to Tampubolon (reading is a physical and mental activity. Through reading information and knowledge that is useful for life can be obtained. That is the main motivation that can encourage the growth of interest in reading.

Reading according to Hodgson as quoted by linguists, is a process carried out and used by readers to obtain the message to be conveyed by the author through the media of words or written language.

Understanding of reading according to Klein (in Rahim, 2005: 3) suggests that the definition of reading includes: (1) reading is a process, (2) reading is strategic, and (3) reading is interactive. Reading is an intended process of information from the text and the knowledge possessed by the reader has a major role in shaping meaning. Reading is strategically interpreted that effective readers use various reading strategies that are appropriate to the text and context in order to construct meaning when reading. This strategy varies according to the type of text and the purpose of reading. Reading is interactive is the involvement of the reader with the

18 Azyumardi Azra, "Pesantren: Continuity and Change, " An Introduction to the Nucholis Madjid, room-room boarding school, h.xxiv . 
text depending on the context. People who like to read useful texts will meet several goals that they want to achieve. The text that someone reads must be easily understood (readable) so that interaction occurs between the reader and the text.

From the thoughts expressed, it can be concluded that reading skills are physical and mental activities to understand written symbols so that the reader catches the message conveyed by the writer so that the interaction of information between them occurs. By paying attention to the understanding of reading skills, it can be defined that the reading activity itself is one of the language skills included in the rhetoric like other language skills. In reading activities, readers need well-structured knowledge and skills. This is confirmed by Hamid's statement, et al. (2008: 46) that reading is one of the language skills that is not easy and simple, not just sounding letters or words but a skill that involves a variety of mind and mind work. Reading is an activity that includes all forms of thinking, giving judgment, making decisions, analyzing, and finding solutions to problems.

Reading should have a purpose, because someone who reads with a purpose, tends to understand more than someone who has no purpose. In reading activities in class, the teacher should set up reading goals by providing specific objectives that are appropriate or by helping them set up students' reading goals themselves. The purpose of reading is to search for and obtain information, including content, as well as reading comprehension. The meanings and meanings are completely related to the purpose of reading. Following are presented some of the important goals regarding reading skills, namely: 1). Read to get the details or facts (reading for details or fact). 2). Read to get the main ideas (reading for man ideas). 3). Reading to find out the order or arrangement, organization of the story (reading for sequence or organization). 4). Reading to conclude, intensive reading (reading for inference ). 5). ${ }^{19}$ Reading to classify (reading for classifity ).6). Reading to evaluate or evaluate (reading for evaluate).

In general, the ultimate goal of teaching reading is for students to have the skills to read and understand Arabic texts, not only text that has been adapted but new texts in real life. From some of the opinions above, it can be concluded that the purpose of reading other than for pleasure is to renew and infer knowledge or information, find ideas, confirm predictions, and assess and answer specific questions. According to Effendy reading skills contain two aspects, namely:

${ }_{19}$ Males Sutiasumarga, Arabic Literature, Zikrul Hakim, (East Jakarta: 2000), 68. 
1) The aspect of changing the writing symbol into sound.

The Arabic alphabet has a different system from the Latin alphabet. Another difference is the Arabic writing system that starts from right to left, does not recognize uppercase letters with a certain form to) start a new sentence, write the name of a person or place, and different forms of Arabic letters when standing alone, at the beginning, in the middle, and at the end.

2) Aspects of understanding the meaning of reading.

There are three elements that must be considered and developed in students reading for this understanding, namely the elements of words, sentences, and paragraphs. These three elements together support the meaning of a reading material. According to Brougton in general there are two important aspects of reading: Mechanical skills (mecanical skills) that can be considered to be in a lower order (lower order ). This aspect includes: a). introduction to the form of letters. b). introduction to linguistic elements (phonemes / graphemes, words, phrases, clause patterns, sentences, etc.). recognition of relations or correspondence of spelling and sound patterns, and. d). reading speed is slow.

Skills that are understanding (comprehension skills) that can be considered to be in a higher order (higher order) include: a. understand simple terms (lexical, grammatical, and rhetorical) b. understand the significance or meaning of the author's intent and purpose according to the circumstances, culture and editor's reading. evaluation and assessment (side and form), and. d. flexible reading speed, which is easily adapted to the circumstances.

Of the two opinions have the same purpose, namely that aspects of reading are aspects of changing, understanding written symbols and meaning of reading to start new sentences and obtain information about a matter, to understand in detail and overall the contents of the reading, to assess and evaluate the truth of ideas reader.

3) Types of Reading.

According to Effendy to train two aspects of reading skills, there are several types of reading, including: 1). Read out loud. In this hard reading activity, the first thing to emphasize is the ability to read by: a. Maintaining the accuracy of Arabic sound both in terms of makhraj and other sound characteristics. B. The right rhythm and expressions that describe the feelings of the author. c. Smooth and not halting. d. Pay attention to punctuation marks.2). Reading silently aims to gain understanding, both the points and the details. In the activity of reading silently, need to create an orderly classroom atmosphere that allows students to concentrate on 
their reading.3). Speed reading. The main purpose of speed reading is to encourage students to dare to read faster than their habits.

In this speed reading, students are not asked to understand the details of the contents, but enough with the points. But keep in mind that not every reading material can be used as a speed reading material, among scholars who pay attention to vowels / reading. ${ }^{20}$ 4). Recreational reading. The purpose of recreational reading is to provide students with training in speed reading and enjoy what they read. The aim is further to foster interests, skills and love of reading.5). Read analysis. The main goal is to train students to have the ability to find information from written material. Students are trained to be able to explore and show details that reinforce the main ideas presented by the author.

While in terms of whether or not the readers' voices are heard, the reading process is divided into reading aloud and reading silently. reading aloud is an activity that is a tool for teachers, students, or readers together with other people or listeners to capture and understand the author's information, thoughts, and feelings. Reading silently is reading silently. Further said that, reading silently can be divided into two, namely: a. Extensive Reading, i.e. read as much of the text as possible in the shortest time possible. The purpose of extensive reading is to quickly understand important content efficiently. Extensive reading includes survey reading, skimming, and shallow reading. b. Intensive reading, including reading content reviews and reading language studies. Then read the contents review divided into reading carefully, reading comprehension, critical reading, and reading ideas or ideas. Reading the language itself includes reading, reading language and reading literature. From the types of reading above, researchers take the type of analytical reading or intensive reading as one type of reading used for research. Because in that sense it means to increase the ability to find information or find ideas from written material.

\section{E. Steps for Teaching Nahwu. ${ }^{21}$}

Most books compiled lately follow the استقر ائية method with its two branches as described above. Therefore, the teaching step will be limited to the Herbart System teaching method as a good example for the method. استقرائية; This method is carried out through the following stages: Preparation stage (preliminary).

${ }^{20}$ Ahmad Sayuti Anshari Nasution, Beep Language, UIN Press (Jakarta: 2006), Cet I, 61 .

$$
21 \text { الخلي أمين، مناهج تجديد : في النحو والبلاغة والثفسير والأداب، دار المعرفة (مصرى : 1961) ص-47. }
$$


In the preparation step, the teacher must prepare all the material for the lesson to be presented, then the teacher starts with introductory introductory questions or examples in the cawaid section that have been studied previously that relate to the subject matter being taught now, meaning the teacher must have an apperception on the past lesson with the lessons to be given, what is the relationship between the subject matter kawaid with each other is strong. In this introduction, the teacher must emphasize on the explanation of the meaning side, where students must be

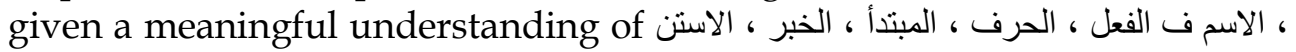

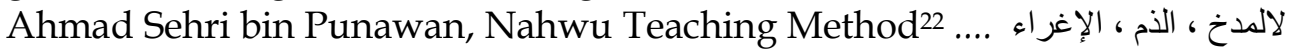
as well as other terms in Nahwu science. This preliminary step is intended to attract the attention and concentration of students so that they easily imitate the new lessons. The stages of presenting examples or perfect texts. apperception, the next step the teacher begins to provide subject matter begins with young things towards difficult material and from concrete to the extracted.

Therefore, in this sample method, the teacher writes the examples on the board, both the examples made by the teacher and students after they receive several questions from the teacher. There is nothing wrong if the teacher wants to write some additional examples on separate papers and then share them with the students. As for the perfect text method, the teacher writes the text on the blackboard, or has written it down on paper, then shares it with students. After that, the teacher explains the text as he explains the material قراءة namely by introducing, reading, and explaining the meaning of the vocabulary then discussing the general meaning of the text earlier. Because the teacher must cite examples from the existing text, the teacher asks questions to students whose answers are sentences that can produce a formula of rules, then the examples answered by students are written on the board while underlining the desired word or written in color, then give the final line.

The examples proposed should be sufficient, because if the example is limited it will reduce even the weight of the rule to be made. Besides that, insufficient examples will lead to mistakes, because the rules that will be made can be done in a hurry. It is better if the example is sufficient in addition to strengthening the value of the rules themselves, it will give a deep impression on the minds of the students. The phase of weighing and matching After the presentation process is complete, the teacher must associate and combine the lesson then with a new lesson, so the lesson has

22 Ahmad Sehri Bin Punawan, Teaching Nahwu, Diktat MK PBA STAIN Datokarama Palu, (Palu: 2009),24. 
a close relationship. In this case, the teacher seeks to meet between the parts of the text or examples that have been presented, so that students learn the points of similarities and differences. between parts or examples. The more careful the teacher meets the similarities, the greater the expectations for achieving the target, as well as the success of the subject depends on the intelligence of a teacher in associating old lessons with new lessons because teachers play a role as directors, guides, and correctors.

The students must act as a team to find points of similarity and difference, compare and bring together, then conclude in the form of rules. The stage of formulation of rules (organizing materials) Next, organizing new materials with old ones as a result of association relations which becomes a compact and complete understanding system. If a teacher has successfully carried out the steps before then it will be easy for students to arrange and organize the knowledge and experience gained from some of the above processes in the formulation of rules, and if there is a terminology that they don't know then the teacher must teach it briefly, after that the teacher must write rules that have been designed by students on the board faced with examples, in this formulation must involve all students or at least their majority, so that the rules become more compact and comprehensive. After that, the teacher reads the rules of the formula, then assigns students to read them in a manner take turns.

The application stage As a final step, the teacher gives practice questions and practices the results of the lesson that has been given. Strictly speaking, to solidify the formulation of the rules that have been made, the teacher must provide training to students. This is Ahmad Sehri bin Punawan, Nahwu's Teaching Method ... intended to measure the weaknesses of students to improve; maybe that is why so many textbooks were arranged lately at the end of each end of the course material must be followed by exercises that are arranged varied, both in the form of questions and question material, so that students' mastery of the rules increasingly pervasive and steady habituation of Reading[.]

\section{REFERENCES}

$$
\begin{aligned}
& \text { أمين، الخلي، مناهج تجديد : في النحو والبلاغة والنفسير والأداب، دار المعرفة (مصرى : 1961). }
\end{aligned}
$$

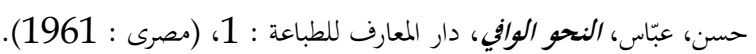

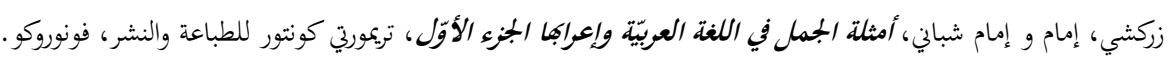

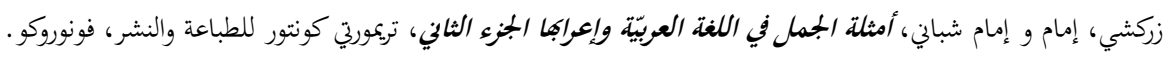

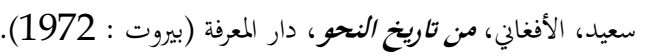


سوترسنو أمد والقسم المنهج الدراسى بكلية المعلمين الإسلامية، علم النحو الجزء الأول، دار السلام للطباعة والنشر،

سوترسنو أمد والقسم المنهج الدراسى بكلية المعلمين الإسلامية، علم النحو الجزء الثاني، دار السلام للطباعة والنشر،

سوترسنو أممد والقسم المنهج الدراسى بكلية المعلمين الإسلامية، علم النحو الجزي الثالث، دار السلام للطباعة والنشر،

Ardianto, Attitude of language Social studies of linguistics, PT .UNM (Malang: 2012).

Azra, Azyumardi, "Pesantren : Continuity and Change, "An Introduction to the Nucholis Madjid, room-room boarding school.

Basyuni, et.al, Analysis, Journal of Islamic Studies, (Lampung; 2006).

Dahlan, Juwairiyah, Arabic Language Teaching and Learning Methods, Al-Ikhlas (Surabaya; 1992).

Effendy, Ahmad Fuad, Arabic Language Teaching Methodology (Malang: Misykat, 2005), 3rd cet.

Fahmi, Ismail, Ulumuna, Journal of Islamic Studies, (Mataram: 2012).

Jamal, Misbahuddin, Understanding the language of the Koran, STAIN Manado Press, (Malang: 2013, Cet I.

Muhammad, Abu Bakar, Special Method of Teaching Arabic, National Business, (Malang; 1981).

Nasution, Ahmad Sayuti Anshari, Beep Language, UIN Press (Jakarta: 2006), Cet I.

Rafi'i,"Ibn Mada's Thoughts and Efforts of Ulama XX Century in Nahwu Reformation.

Santosa, Praise, Knowledge and appreciation of Literature, Nusa Indah (Jakarta; 1996) cet I.

Sehri Bin Punawan, Ahmad, Teaching Nahwu, Diktat MK PBA STAIN Datokarama Palu, (Palu: 2009).

Smith, Jonathan A., Fundamentals of Qualitative Psychology ; Practical Guidelines for Research Methods, (Bandung : Nusa Media, 2006).

Susanto, Ahmad, Philosophy of science : a study in Dimen the Ontological, epistemological and axiological, cet. 2, (Jakarta : Earth Literacy 2001).

Sutiasumarga, Males, Arabic Literature, Zikrul Hakim, (East Jakarta: 2000). 
376 | AKADEMIKA: Jurnal Pemikiran Islam

Vol. 24, No. 02 July - December 2019 